\title{
Contemporary Issues in the Regional Development of Tourism in Croatia
}

\author{
Zoran Curić, Nikola Glamuzina, Vuk Tvrtko Opačić
}

\begin{abstract}
The aim of this research is an analysis of the tourism development of the smallest administrative units (towns and municipalities) as well as their typology within the Croatian tourism regions. The methodological approach is based on GIS analysis of seven relevant indicators of tourism development; this is a tool for defining typology. Such an approach helps in determining the conclusion concerning the role that tourism plays in each administrative unit inside the respective five Croatian tourism regions. Research shows pronounced differences in terms of the level of tourism development between the littoral tourism regions in comparison to the three continental regions. The differences are also visible when analyzing the level of tourism development of towns and municipalities inside the regions. Such a situation is a consequence of the concentration of tourism development at both the national and regional levels, which is more exaggerated in the continental parts of the country.
\end{abstract}

Key words: regional development, GIS analysis, tourism, Croatia

\section{Suvremeni problemi regionalnog razvoja turizma u Hrvatskoj}

Cilj je ovog istraživanja analiza turističkog razvoja najmanjih administrativnih jedinica (općina i gradova) te njihova tipologija unutar hrvatskih turističkih regija. Metodološki pristup temelji se na GIS analizi sedam relevantnih pokazatelja turističkog razvoja, koja služi kao alat za definiranje tipologije. Primjenom takva pristupa došlo se do zaključka o ulozi turizma u svakoj administrativnoj jedinici u pet hrvatskih turističkih regija. Istraživanje pokazuje značajne razlike u dosegnutom stupnju turističkog razvoja između primorskih i kontinentalnih turističkih regija. One su vidljive i u stupnju turističkog razvoja gradova i općina u svakoj pojedinoj regiji. Takva je situacija posljedica koncentracije turizma na nacionalnoj i regionalnoj razini, što je naglašenije u kontinentalnom dijelu zemlje.

Ključne riječi: regionalni razvoj, GIS analiza, turizam, Hrvatska

\section{INTRODUCTION}

Contemporary tourism development in Croatia is characterized by significant geographical unevenness. This fact has led to different approaches in the regionalization of Croatian territory for purposes of tourism research. The dynamics and complexity of tourism development demand more precise methods for the analysis of the regional differences of tourism development. This paper aims to contribute to the areas of tourism regionalization of Croatia and to the quantitative study of tourism, primarily using the GIS analysis as a useful tool of geographic research. 
The hypotheses which this paper aims to research deal with both the application of the GIS methods in tourism analysis and the very process of concentration of tourism development at national and regional levels. This research tends to answer three hypotheses, which are defined in the form of the following questions:

1) Is the use of methodological approaches based on the GIS analysis of relevant statistical indicators possible for the research of polarized tourism development?

2) What are the characteristics of tourism development among the tourist regions in Croatia?

3) What are the geographic characteristics of tourism development inside each tourist region?

As a means of answering the three hypotheses the authors have applied the methodological approach based on determining the typology of administrative units (towns and municipalities) by using the relevant indicators.

\section{THEORETICAL BACKGROUND OF THE RESEARCH}

The Quantitative Revolution, which began in the 1950s, affected regional geography through the development of new paradigms, theories and methodological approaches. Thus, quantitative analysis gained a more important place alongside the analysis of maps and air photos and other methods. Contemporary geography understands regions as essential parts of the socio-spatial structure. The role of any single region can vary from pure ideas to real administrative or economic functions (Paso, 1986). The latter roles have developed in order to facilitate regional planning connected to national and international relations (Die leman and Fluid, 1998) and they occupy an important place in modern society. Therefore, new challenges and opportunities that have arisen for modern geography have given it an increasing relevancy. Because of this, the study of regions has grown in relevancy and complexity (Brunt, 1995).

The complex and rapid social changes that started after World War I accelerated in the 1950s. The integration of the modern world caused the integration of regions and regional economies into the larger socio-spatial context. Because of this, the concept of a traditional region, which was a self-contained and integrated system, slowly disintegrated (Patter, 1989).

During the second half of the $20^{\text {th }}$ century, what is called "new regional geography" appeared. It was based on the criticism of the view of traditional regional geography, which held that the population of the world is segmented into independent societies that are generally dependent on the valorisation of the natural resources which can be found in the respective regions (Verso, 1997). This new concept of regional geography is based on the "new paradigm" and, by now, it has evolved from a multitude of sources. Therefore, it still does not represent one clear body of thought (Holmen, 1995). The different and numerous approaches that have developed up to now can be divided into three groups: political-economic (with an emphasis on economic structures and processes), humanisticphenomenological (approaches which understand region as a place of identification) and structuralistic-theoretical (based on the theory of structuralism, the region is seen as a 
medium of social interaction) (Vresk, 1997a). Since regionalization is still an inevitable step in regional planning, the different approaches each have practical importance (Vresk, 1990). One of the key problems is the choice of relevant indicators and methods for regionalization. Accordingly, there is no one unifying principle of regionalization.

In accordance with the new approaches, the terms homogeneous economic regions, or simply economic regions, appeared. While some economic regions are extremely specialized for one activity (agriculture, industry, mining or certain services such as tourism), others are home to varied activities. Therefore, the terms specialized economic regions and regions of complex economy were introduced in order to define their dominant feature (Claval, 1998). It is necessary to underline the relativity of the terms homogenous and specialized since the scope of their application is very questionable. Homogeneity, on the one side, is ambiguous because regions are homogenous regarding one criterion while, at the same time, they are heterogeneous regarding another (Papić, 1987). The same can be said about the term specialization.

Regional studies in Croatia, in the spirit of "new regional geography," appeared in the 1960s (Rogić, 1962). Although they were followed by corresponding theoretical papers (Rogić, 1963), the concept of the traditional region still prevailed (Rogić, 1983) and was widely used in historical geography (Fürst-Bjeliš, 1996). New regionalizations, which took into consideration the importance of urban centres in the shaping of regions, were published in the 1980s (Rogić, 1984). More complex and relevant studies of Croatia's regional structure (Vresk, 1995), based on the research of processes and their dynamism that put results into theoretical frameworks such as the core-periphery model, were published at the turn of the century (Njegač, 2000).

\section{METHODOLOGICAL APPROACH}

The methodological approach in this research is based on GIS analysis of indicators of tourism development. A key part of the initial phase of the quantitative analysis is the selection of relevant research variables. It is a crucial step in regional geographic research and it requires the researcher's ability to distinguish essential from incidental variables (Nir, 1990).

For the purpose of this research, seven indicators of tourism development have been defined:

1. number of tourist beds;

2. number of tourist arrivals;

3. number of international tourist arrivals;

4. number of tourist nights;

5. number of international tourist nights;

6. number of tourist arrivals per square kilometre;

7. number of tourist arrivals per capita.

It is important to point out that the first five indicators are published by the official national Statistical Bureau at the level of towns and municipalities for the whole country (according to the Croatian administrative division, the country consists of 556 administrative units that are 
called towns and municipalities). The last two indicators, which point out geographic pressure (number of tourist arrivals per square kilometre) and social pressure (number of tourist arrivals per capita) were calculated by the authors on the basis of the official statistical data.

The first step in this work was to divide the Croatian territory into five tourism regions. The next step was to identify all the towns and municipalities inside each region for which tourism data are published. It is important to point out that the aforementioned indicators of tourism development are not published for all the towns and municipalities, since all of them do not feature accommodation facilities and do not have tourism flow. The only exception is the region of the Northern Littoral in which each and every town and municipality has a registered tourism flow.

Tab. 1 The number of towns and municipalities (a), the number of tourist towns and municipalities (b), the tourism development indicators and their values for each tourism region (1-7) in 2009.

Tab. 1. Broj gradova i općina (a), broj turističkih gradova i općina (b), pokazatelji turističke razvijenosti $i$ njihove vrijednosti unutar svake turističke regije (1-7), 2009.

\begin{tabular}{|c|c|c|c|c|c|c|c|c|c|}
\hline REGION & $\mathbf{a}$ & $\mathbf{b}^{*}$ & $\mathbf{1}$ & $\mathbf{2}$ & $\mathbf{3}$ & $\mathbf{4}$ & $\mathbf{5}$ & $\mathbf{6}$ & $\mathbf{7}$ \\
\hline $\begin{array}{c}\text { NORTHERN } \\
\text { LITTORAL }\end{array}$ & 72 & 72 & 475728 & 5275274 & 4763494 & 31441581 & 29317592 & 1636.09 & 18.14 \\
\hline $\begin{array}{c}\text { SOUTHERN } \\
\text { LITTORAL }\end{array}$ & 127 & 92 & 389445 & 389445 & 3702808 & 22284876 & 19742315 & 953.33 & 11.40 \\
\hline MOUNTAINOUS & 26 & 16 & 5690 & 222780 & 168668 & 361867 & 231283 & 39.11 & 3.12 \\
\hline PERI-PANNONIA & 231 & 101 & 24198 & 1018703 & 662770 & 1889680 & 1125292 & 59.77 & 0.85 \\
\hline PANNONIA & 100 & 35 & 4083 & 138182 & 37082 & 274143 & 67844 & 35.38 & 0.28 \\
\hline TOTAL CROATIA & 556 & 316 & 899144 & 7044384 & 9334822 & 56252147 & 50484326 & 544.74 & 6.76 \\
\hline
\end{tabular}

* tourist towns/municipalities are those for which the Croatian Bureau of Statistics publishes data of tourism flow Indicators: 1- Number of tourist beds, 2 - Number of tourist arrivals, 3 - Number of international tourist arrivals, 4 - Number of tourist nights, 5 - Number of international tourist nights, 6 - Number of tourist arrivals per square kilometer, 7 - Number of tourist arrivals per capita

Source: Tourism - Cumulative Data, 2009, Statistical Report 4.4.2, Croatian Bureau of Statistics, Zagreb, 2010.

* Turistički gradovi/općine jesu oni za koje Državni zavod za statistiku publicira podatke o turističkom prometu.

Pokazatelji:1 - broj turističkih postelja, 2 - broj turističkih dolazaka, 3-broj međunarodnih turističkih dolazaka, 4 - broj turističkih noćenja, 5 - broj međunarodnih turističkih noćenja, 6 - broj turističkih dolazaka po $\mathrm{km}^{2}, 7$ - broj turističkih dolazaka po stanovniku.

The following step was to analyze all of the towns and municipalities inside a region, taking into account all of the seven indicators of tourism development. The values for each indicator were classified into five groups, applying the Jenks optimization method that 
identifies natural breaks in the data set. On the basis of the results, each town and municipality was assigned a level of tourism development on a scale of one to five, as follows:

$$
\begin{aligned}
& 1 \text { - very low; } \\
& 2 \text {-low; } \\
& 3 \text { - moderate; } \\
& 4 \text { - high; } \\
& 5 \text { - very high. }
\end{aligned}
$$

After the analysis of all the indicators, every town and municipality with a tourism flow had seven marks that were used to calculate the mean average value. In the end, all were assigned a mark indicating their overall tourism development on the scale from one to five. This procedure was done for towns and municipalities of every tourism region.

It is also important to stress that the final marks for the towns and municipalities are not comparable on the regional level, since regions differ significantly among themselves regarding the seven tourism indicators (Tab. 1). Therefore, the threshold values for each of the five classes for the same indicator differ from one region to another.

\section{SHORT OVERVIEW OF THE JENKS OPTIMIZATION METHOD}

During every classification, the data lose a certain amount of their precision. How one can diminish this problem and form classes that are internally homogenous, while at the same time keeping the heterogeneity among them is an issue that has been occupying various scientists. As an answer to this problem, G. F. Jenks introduced the concept of the measurement of the statistical error of a certain classification (Andrienko et al., 2001).

The problem of the selection of class intervals has been widely analyzed in scientific literature (Evans, 1977). In recent days, more scientific papers seem to be appearing, which emphasize this problem along with the problem of minimizing the loss of information during the process of visualization (Pászto et al., 2009).

The Jenks method, or optimized methods, are names that are assigned to a group of classification methodological approaches designed by George Jenks and his associates. They have been created in order to minimize variations within classes, while searching for the optimal classification algorithm (Jenks and Coulson, 1963).

The best known method is the Jenks optimization method, also known as the method of "natural breaks," which identifies break points among classes by minimizing the sum of variance within each class. The method determines boundaries while at the same time minimizing the average of a squared deviation in every class; because of this, the boundaries are set where there are relatively big jumps in the values. The method also identifies groupings and patterns inherent in the data. As a result, it produces a more objective aggregate representation of spatial variability (Jenks, 1967.).

The method of natural breaks has been widely used for the mapping of quantitative data, since it aims to provide the most appropriate class ranges by comparing them with the distribution of the whole dataset. The result of such an approach is that the obtained class ranges mirror the structure of the data distribution (Jenks, 1977). 
The usefulness of the method, simply called the Jenks natural breaks method, has by now been shown for the analysis of various geographic phenomena such as urban growth (Mennis and Liu, 2005), property crime rates in a city (Murray and Shyy, 2000), scaling of geographic space from the perspective of city and field blocks (Jiang and Liu, 2011), the visual presentation of terrain elevations (Rana and Morley, 2002), the mapping of poverty (Holt, 2007) or of poverty and environmental vulnerability (Hall et al., 2008), population density (Graeff and Loui, 2008) and the mapping of other demographic data (Weaver, 2006).

The Jenks optimization method has been used in research by various scientific branches such as geology (Batterson and Taylor, 2005) and in the analysis of different processes such as commuting patterns in work-related movement, which can help to predict workplace contacts that result in disease transmission (Chrest and Wheaton, 2009).

A similar research concept to that of this paper, together with the Jenks optimization classification method, has been successfully applied in defining the homogeneous environmental management units of the Catalan coast (Brenner et al., 2006).

It is also important to mention that some researchers emphasize that the Jenks method of natural breaks is not the best suited for choropleth maps, giving the advantage to other methods such as quantiles or minimum boundary error (Brewer and Pickle, 2002). On the other hand, the Jenks natural breaks method has been proven to be the most accurate when compared to other methods, at least in the case of the analysis of data that has clear breakpoints (Osaragi, 2002).

\section{RESULTS}

Regionalization of Croatian territory for tourism purposes - The traditional regionalization of Croatia from the point of view of tourism geography recognizes three tourism regions: the Littoral (also called Mediterranean or Adriatic Region), the Mountainous Region and Pannonian-Peripannonian Region. Such a division was designed in the 1980s by Croatian geographers (Blažević and Pepeonik, 2002) and has been in use for academic purposes as well as educational ones (Blažević, 2009).

In this paper the traditional regionalization has been updated, since Croatian tourism in the meantime has experienced various changes in the sense of the overall tourism development. It is not a surprise that such development has not been geographically even and, because of this, the differences among the tourism regions, just as inside each region, have became more pronounced. The geographically uneven tourism development has been especially evident in the Littoral and Peripannonian-Pannonian regions. This is the reason why the authors of this paper find it necessary to modify the traditional tourism regionalization of the Croatian territory by dividing the latter two regions. Therefore, the Littoral has been divided into the regions of the Northern and Southern Littoral, while the Peripannonian part of the country has been divided from the Pannonian into a separate region (Fig. 1).

\section{General characteristics of Croatian tourism regions}

The main geographic characteristic of Croatian tourism flow is an extremely uneven distribution. The majority of tourism is concentrated in the Littoral, where $96.2 \%$ of all tourist beds are located and where the largest part of tourism flow takes place (Tab. 1). 


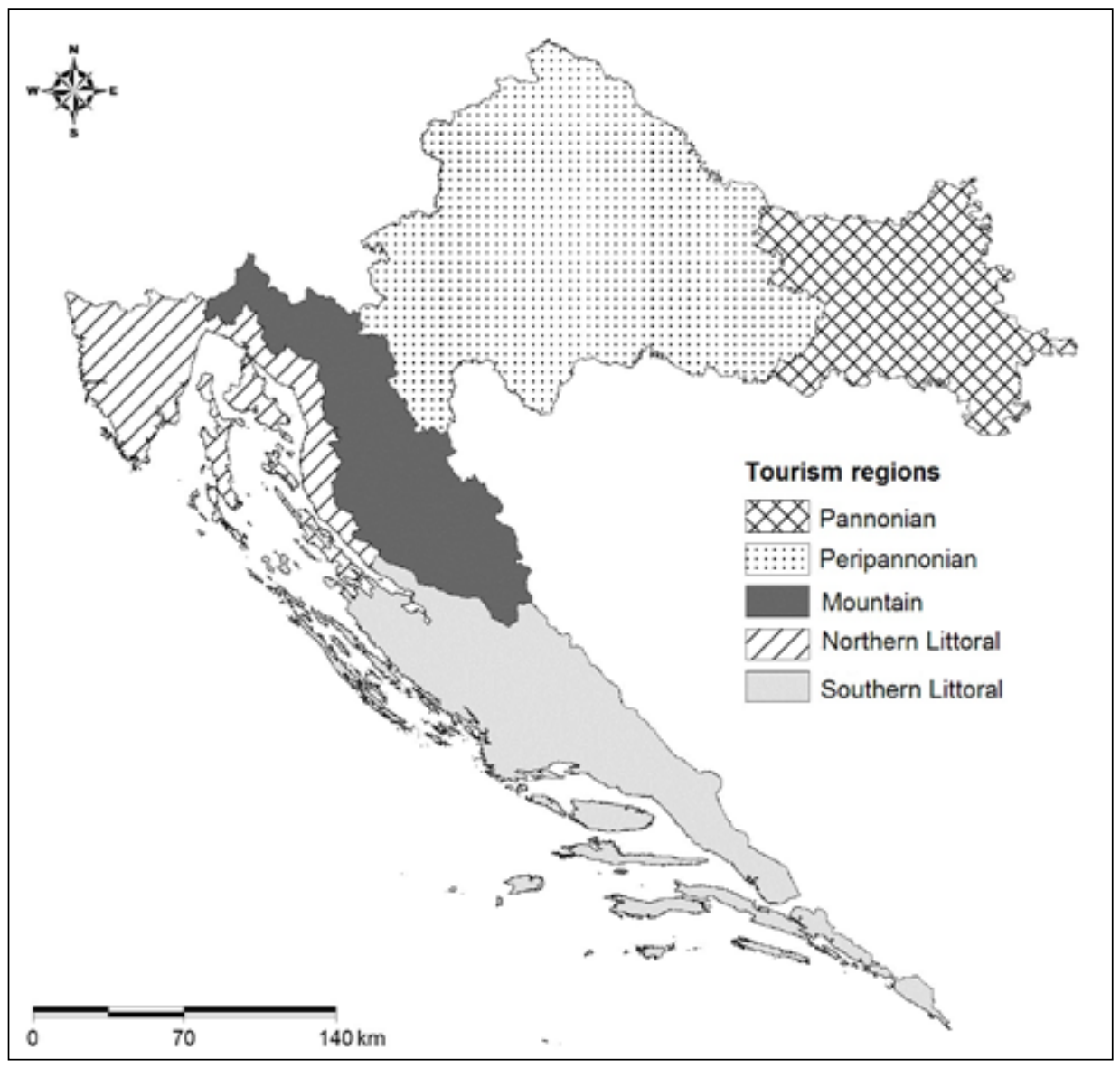

Fig. 1 Croatian tourism regions

Sl. 1. Hrvatske turističke regije

Tab. 2. Percentages of each tourism region in the overall tourism flow in 2009.

Tab. 2 Postotni udjeli pojedinih turističkih regija u ukupnome turističkom prometu 2009.

\begin{tabular}{|c|c|c|c|c|c|}
\hline REGION & $\begin{array}{c}\text { Tourist } \\
\text { beds }\end{array}$ & Arrivals & $\begin{array}{c}\text { International } \\
\text { arrivals }\end{array}$ & $\begin{array}{c}\text { Tourist } \\
\text { nights }\end{array}$ & $\begin{array}{c}\text { International } \\
\text { tourist nights }\end{array}$ \\
\hline NORTHERN LITTORAL & 52.9 & 48.2 & 51.0 & 55.9 & 58.1 \\
\hline SOUTHERN LITTORAL & 43.3 & 39.1 & 39.7 & 39.6 & 39.1 \\
\hline MOUNTAINOUS & 0.6 & 2.0 & 1.8 & 0.6 & 0.5 \\
\hline PERI-PANNONIA & 2.7 & 9.4 & 7.1 & 3.4 & 2.2 \\
\hline PANNONIA & 0.5 & 1.3 & 0.4 & 0.5 & 0.1 \\
\hline TOTAL CROATIA & 100 & 100 & 100 & 100 & 100 \\
\hline
\end{tabular}

Source: Tourism - Cumulative Data, 2009, Statistical Report 1408/2010, Croatian Bureau of Statistics, Zagreb, 2010. 
The Littoral accounts for $86.4 \%$ of all tourist arrivals and for $95.5 \%$ of all tourist nights. It is a part of Croatia that international tourists visit the most, since $90.7 \%$ of all international arrivals are registered there and as much as $97.1 \%$ of international tourist nights are registered there (all the data is for 2009). The Littoral consists of two tourism regions: the Northern and Southern Littoral. They have similar natural features that are relevant for tourism development: situated on the Adriatic coast with a typical Mediterranean climate (which in the interior transforms into sub-Mediterranean), dynamic karstic relief and characteristic Mediterranean vegetation marked by various coniferous trees (pine, cypress, spruce) and shrub vegetation (macchia). Because of the pleasant temperatures of the sea water, large insolation and dry summer weather, it is one of the principal areas of interest for national and international tourists.

Although the two regions are oriented toward the same type of tourism - mass beach tourism - there are certain difference in their development. In the first place it is important to point out the higher level of tourism development of the Northern Littoral region, which is illustrated by the data of tourism flow. In every sense the Northern Littoral is the most important tourism region in Croatia, where more than one half of the national tourism takes place. Such a high level of tourism development is a consequence of several features. The first is the favourable geographic situation of the Northern Littoral in relation to the principal national and international emissive regions from which the majority of tourists come. Close to the region and centred around the Croatian capital of Zagreb, which generates the majority of national tourists and is connected with modern motorways, the Northern Littoral is easily accessible to the majority of Croatian visitors. On the other hand, it is also close to certain parts of Europe that are important emissive regions of tourists, such as northern Italy, Slovenia, the Alpine countries, southern Germany and Hungary. The second important feature of its tourism development is the wider basis of tourism options, since the Northern Littoral has more varied types of tourism. Although beach tourism still takes the principal role, new types of tourism has been successfully introduced and are constantly increasing: agritourism, medical (dental), nautical, culinary, hunting, heritage, culture tourism and wine routes. The region also features the best human resources in the tourism sector which, combined with the strong enterprising spirit of the local population, makes it the most important tourism area in the country.

The Southern Littoral is the second Croatian Mediterranean region. It is characterized by similar natural features to the Northern Littoral, with some differences, one of them being higher temperatures and greater insolation. The southern part of the Littoral also features a longer coastline, which is especially attractive for tourism development. However, it still does not have the same level of tourism development, since the values of the tourism indicators are approximately 10-20\% lower than those of the Northern Littoral. One of the reasons for such a situation is to be sought in the larger distance from the already mentioned principal national and international emissive tourist regions, a problem which has been only partially resolved by the construction of a modern national motorway and the strengthening of air transport connections. Nevertheless, the tourism importance of the Southern Littoral is obvious, since it accounts for some $40 \%$ of the national tourism economy. The region's tourism is still concentrated along the very continental and insular coastline. Such a geographic distribution is the consequence of the total prevalence of beach tourism. Although the region has made certain steps toward more diverse tourism development since the beginning of the $21^{\text {st }}$ century, especially in case of culture tourism, results are yet to be seen. 
The Mountainous Region is situated in the very hinterland of the Littoral and it presents a junction between the Croatian Littoral and the interior of the country. Therefore, it has a crucial transit role for visitors who come to the Littoral using surface traffic. It is a region with the most dynamic relief, characterized by the highest mountain ranges, which abound in snow during the winter months. Therefore it possesses many unspoiled natural beauties, which are represented by the most famous and the most visited Croatian National Park, Plitvice Lakes. However, the region accounts for only $0.5-2 \%$ of the national tourism (depending on the indicator) and is considered to be an area of many unused tourist attractions. The reasons for this are to be sought in the general developmental problems that burden the region, which can be especially seen in constant population loss and population ageing, the lack of a qualified tourism workforce, insufficient encouragement of tourism development from the local authorities, and similar factors. At the present moment, tourism in the Mountainous Region is concentrated inside the three National Parks, with focus on the Plitvice Lakes. The significant potential for the development of winter sports and recreational tourism has still not been realized and only a few destinations with inadequate infrastructure in the northern part of the region attract aficionados of winter sports.

The Peripannonian region consists of areas covered by hills, uplands, valleys and wide alluvial plains. It has a sharp moderate continental climate with the regular appearance of cold days during the winter and hot days in the summer. The most attractive natural areas are situated in the uplands where three Nature Parks have been designed. Up until now, only a few of the natural resources have been chosen for tourism development. The Peripannonian Region dominates in thermal tourism, since the majority of Croatian spas are located in this part of the country. The region also abounds in Baroque castles that are not used for tourism, excluding a few exceptions. The region is regarded as the most important emissive tourist part in Croatia, since more than half of the nation lives there and because it is the most developed part of the country. From the point of view of receptive tourism it is important to stress that it is the most important continental tourism region in Croatia. Although it accounts for approximately $9 \%$ of all tourism arrivals and $7 \%$ of international tourism arrivals, the region has a very low share of tourism beds and tourism nights. The focal tourism point is the Croatian capital of Zagreb, the centre of a large urban region with approximately 700,000 inhabitants. Zagreb is the most important destination in the country from the point of view of tourism manifestations (especially for concerts and various sport tournaments) and cultural institutions (primarily museums). Other bigger towns do have interesting cultural-historical monuments, but only Varaždin has managed to promote them for tourism purposes up until now. The region also has immense traffic importance since Zagreb is the most important motorway junction in Croatia and possesses the busiest airport.

The Pannonian region stretches through the eastern part Croatia. It is an area of eponymous plains and contains very limited natural attractions from the point of view of tourism development, since it is characterized by a monotonous relief and climate extremes in the sense of temperatures. The best-used tourism attractions are the spas at Bizovac and the Nature Park of Kopački rit (a Ramsar Convention site) near Osijek, the principal urban centre of eastern Croatia. At the turn of the century, wine routes and culinary tourism have seen a constant rise. However, the Pannonia region still has the lowest importance from the point of view of Croatian tourism and its percentage shares are generally less than $1 \%$. 


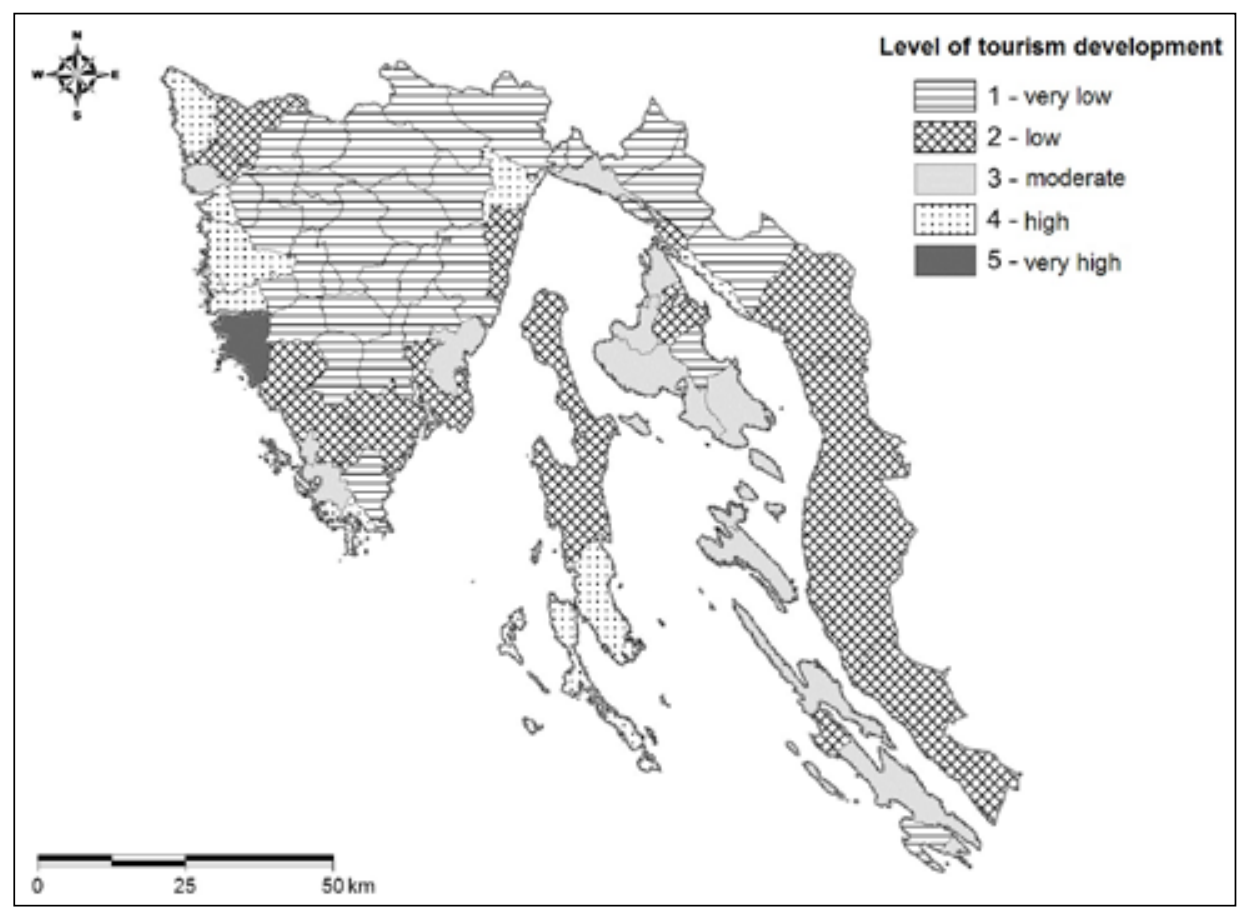

Fig. 2 Level of tourism development of the administrative units in the Northern Littoral region in 2009 Sl. 2. Razina turističke razvijenosti administrativnih jedinica u Sjevernom primorju 2009.

The peripheral situation inside the national territory, large distances from the principal emissive tourist regions and its small transit importance for international tourists does not encourage future tourism development. The distance from the principal tourism regions on the Adriatic coast, where the majority of tourists spend their vacations, means that the Pannonian region cannot expect the kind of positive influence of the Northern and Southern Littoral in terms of tourism expansion as the Mountainous region does.

\section{Results of GIS analysis}

The GIS analysis applying the Jenks method of natural breaks generally shows the differences between the two Littoral regions on one side, and the three continental regions on the other. The difference is the most obviously seen in the prevalence of extensive areas with no tourism activity in the continental regions.

When comparing the Northern and Southern Littoral, the first striking feature is the geographical distribution of tourism activity. In the Northern Littoral, tourism exists in every part - the coastline, the islands and the interior - while throughout a significant part of the Southern Littoral's interior tourism is nonexistent.

The cartographic representation of the results obtained by the GIS analysis shows the peripheral situation of the focal points of tourism development inside the Northern 
Littoral (Fig. 2). The most important tourism towns and municipalities are located along the Western coast of the Istrian peninsula (from north to south): Umag, Tar Vabriga, Poreč, Funtana, Vrsar, Rovinj (with the best results of overall tourism development in the whole region) and Medulin. Opatija and Crikvenica in the central part of the coastline are in the same group, along with the insular town of Mali Lošinj, situated on the southern edge of the region, which comprises the island of Lošinj and the southern part of the nearby island of Cres. The results also show that the towns and municipalities with moderate tourism development are mostly situated on islands, while those of low and very low tourism development occupy a continuous area that stretches from north to south. The largest example of this type of area is found in the interior of the Istrian peninsula, but it also can be found along its western and eastern coasts, along with the other parts of the region (the islands, coastal part of the continent).

The geographic distribution of the tourism towns and municipalities in the Southern region shows, as expected, that the most developed ones are situated along the coast (Fig. 3). The analysis shows the spatial discontinuity of the four areas of high and very high levels of tourism development. The town of Dubrovnik, at the southern point of the region, is a famous tourist destination worldwide and it shows the highest values of tourism indicators (the administrative territory of the town also stretches to the nearby small archipelago). The second zone is situated in the central part of the region and consists of five administrative units. It is an area called the Makarska Littoral with the town of Makarska as the focal tourism point. The third zone is situated further to the north, with

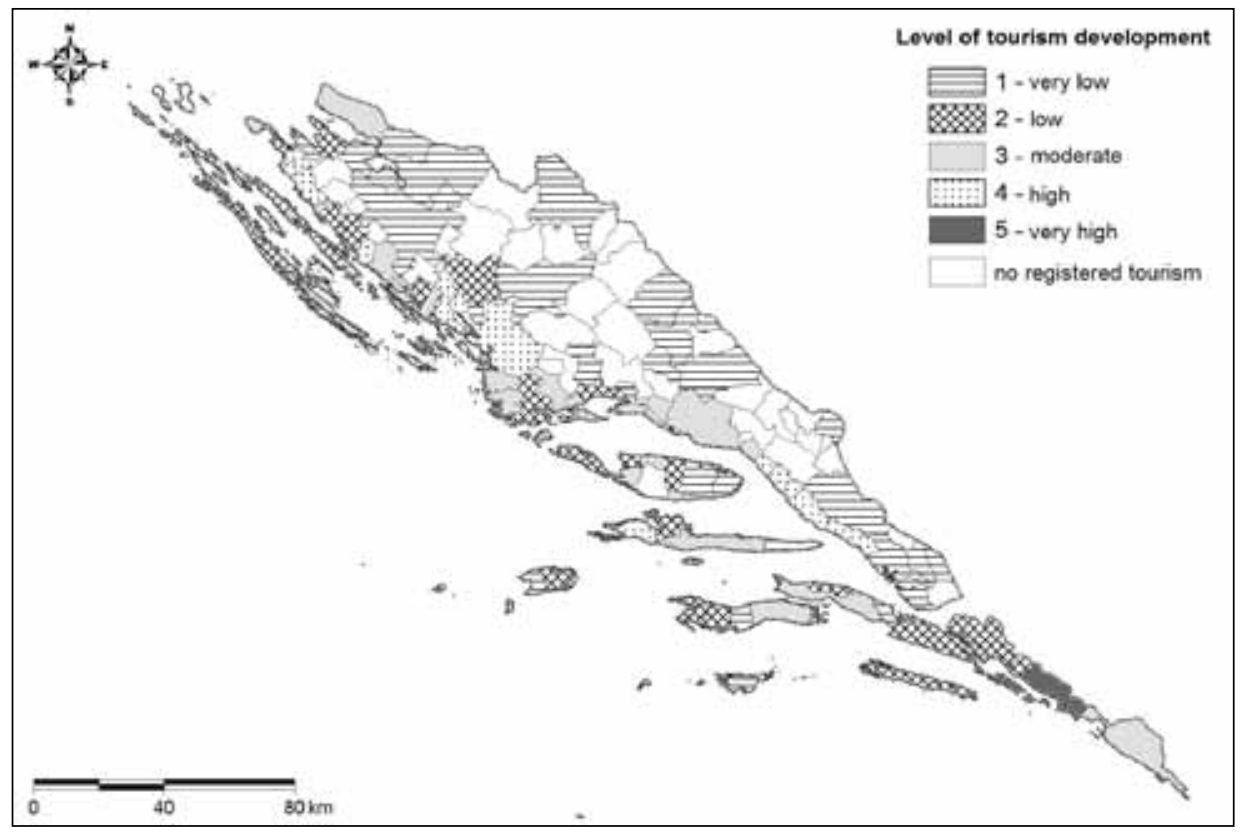

Fig. 3 Level of tourism development of the administrative units in the Southern Littoral region in 2009

Sl. 3. Razina turističke razvijenosti administrativnih jedinica u Južnom primorju 2009. 


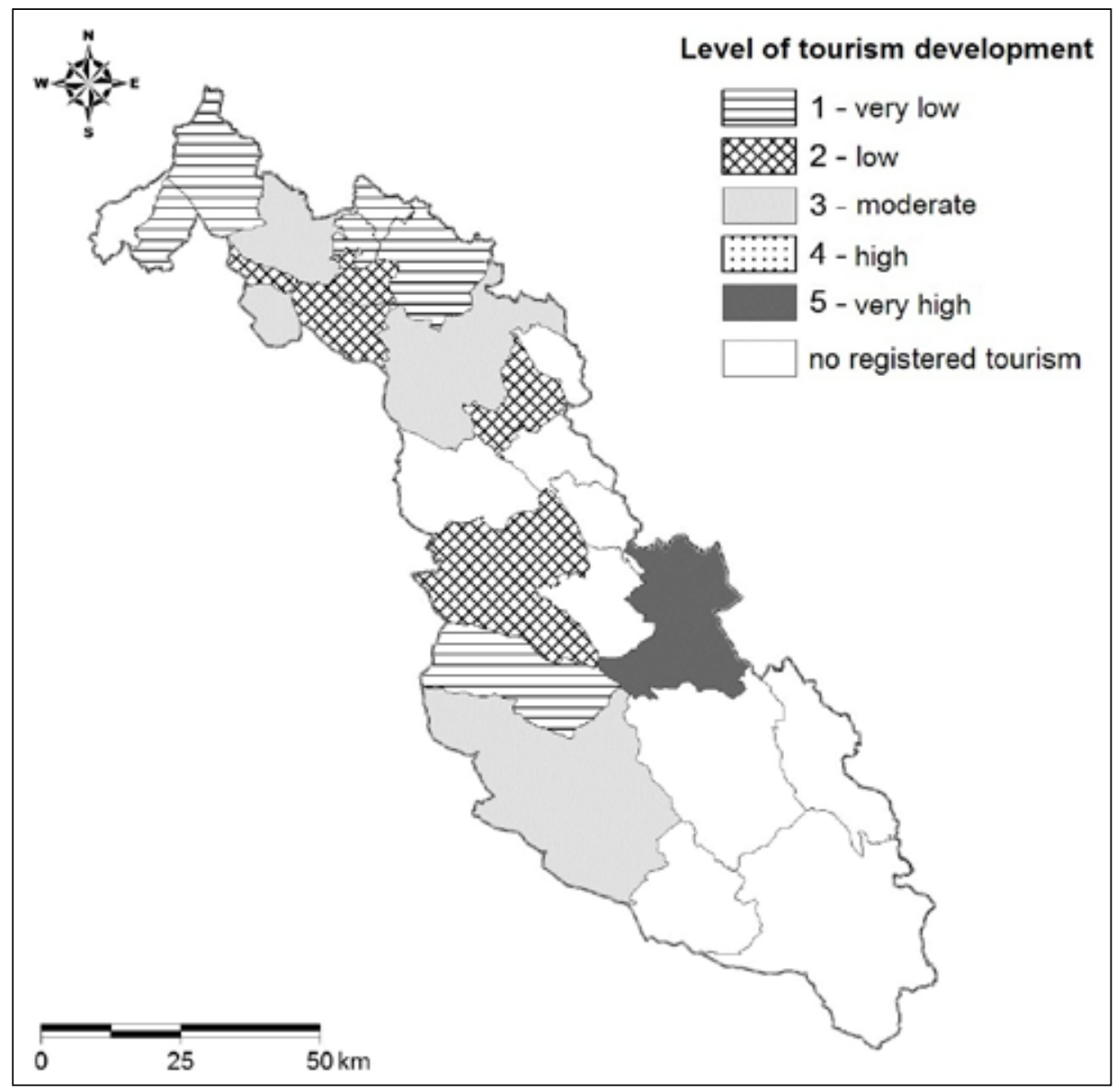

Fig. 4 Level of tourism development of the administrative units in the Mountainous region in 2009 Sl. 4. Razina turističke razvijenosti administrativnih jedinica u Gorskoj regiji 2009.

its centre in the town of Šibenik, one of the principal destinations in the northern part of the region. At the very north is the fourth zone where the town of Zadar is located (the administrative territory of which also comprises the nearby small archipelago, just as with Dubrovnik). Outside of the four named zones of high level tourism development, there is only the western part of the island of Hvar, where the eponymous town is situated. One of the differences between the Northern and the Southern Littoral is the geographical distribution of the administrative units with a moderate level of tourism development. In the Southern Littoral, only a few of them are situated on the large islands, while the majority is located next to the zones of the highest tourism development, forming a certain type of prolongation. The largest part of the region still has a low level of tourism development, primarily in the hinterland, where a significant portion of administrative units does not have any tourism activity at all. The majority of towns and municipalities on the islands, 


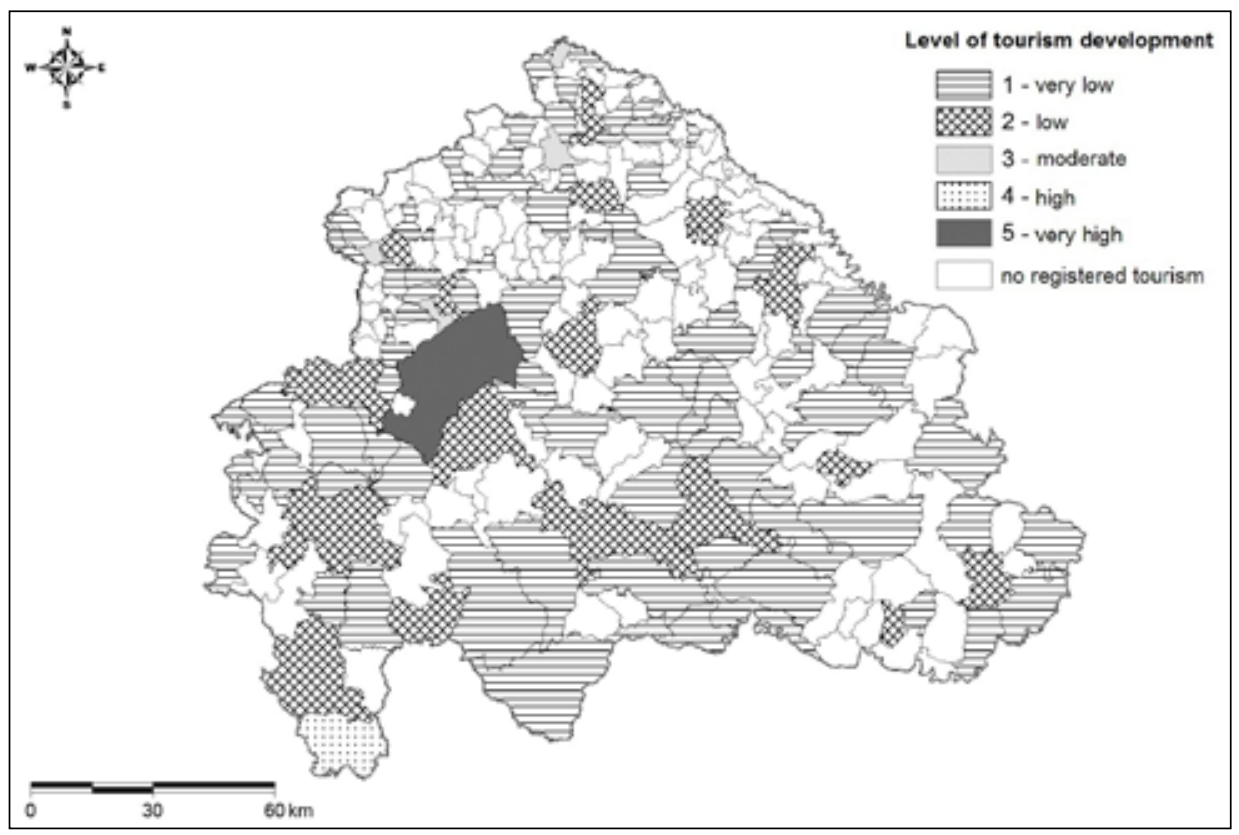

Fig. 5 Level of tourism development of the administrative units in the Peripannonian region in 2009

Sl. 5. Razina turističke razvijenosti administrativnih jedinica u Peripanonskoj regiji 2009.

especially on the smaller ones, are characterized by low and very low levels of tourism development when compared to the destinations on the continental coastline.

Comparison of the results for the three continental regions shows that each one of them is characterized by almost monocentric tourism development, since the dominance of one administrative unit is extremely emphasized.

The Mountainous Region mostly consists of towns and municipalities that either have no tourism activity or are at a low or very low level of tourism development. Although the focal point of the region's tourism is located in the southern part (the municipality of Plitvice Lakes), that segment of the region lags behind significantly when compared with the northern part (Fig. 4). The Plitvice Lakes dominate the region's tourism because of the internationally famous eponymous National Park, which is on the UNESCO World Heritage Sites List.

The Peripannonian region occupies the largest part of the continent. It is still of very small tourism importance, with many administrative units involving no tourism activity (Fig. 5). Although the region's territory is very rounded and compact, the geographic distribution of administrative units involving the most developed tourism is peripheral. The leading place belongs to the national capital of Zagreb, followed by the municipality of Rakovica, which is situated at the northern edge of the Plitvice Lakes National Park. Four spa destinations north of Zagreb (Tuhelj, Sveti Martin na Muri, Stubičke and Varaždinske Toplice) are the sole points of moderate tourism development. The majority of 


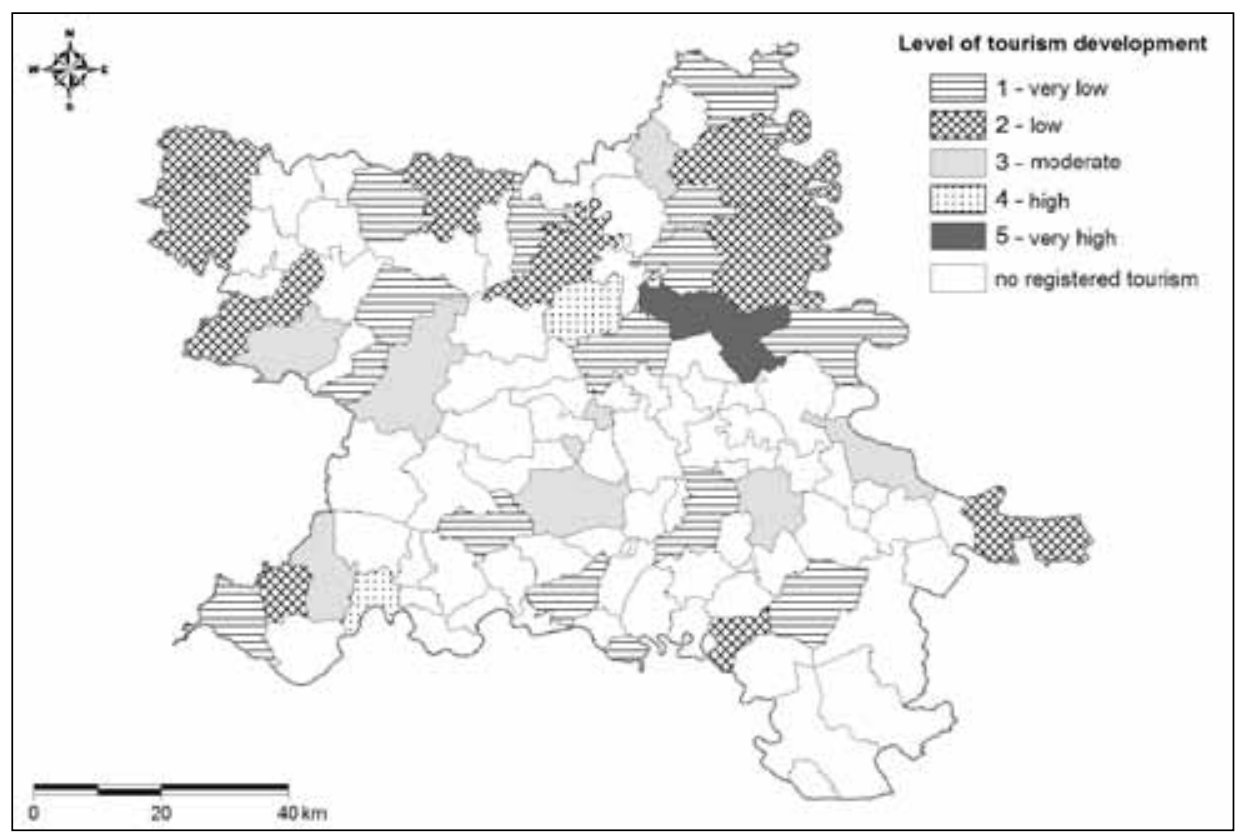

Fig. 6 Level of tourism development of the administrative units in the Pannonian region in 2009 Sl. 6. Razina turističke razvijenosti administrativnih jedinica u Panonskoj regiji 2009.

the region, when compared with other administrative units, has either a low or very low level of tourism development.

The Pannonian Region also has a peripheral distribution of units with registered tourism flow (Fig. 6). The majority of them is concentrated in the northern, especially north-eastern, segment, where the town of Osijek, the principal tourism destination, is situated together with the spa destination of Bizovac (which shows a high level of tourism development). Another town with a high level of tourism development, Slavonski Brod, is located in the south-western periphery of the region. The units with a moderate level of development can be found in various parts of the region, while those at a low and very low level show the tendency of geographical concentration in the Osijek-Bizovac area.

\section{DISCUSSION}

General tourism development in Croatia, along with its various aspects, is regularly discussed in the national scientific literature and it features a tendency to stress the economic side. With an emphasis on the economic benefit from the expansion of the tourism sector, the geographic dimension (including different geographic issues that are initiated by tourism expansion) is often overlooked or simply ignored.

The results of the analysis provide us with substance for a better understanding of the geographic dimension of contemporary tourism in Croatia. For the purpose of a more 
systematic analysis, they can be classified into three groups. The first one deals with the geographic implications of polarized tourism development on the national level. The second deals with the geographic aspect of tourism development inside the regions. The third deals with question of how to focus on tourism development in the near future.

\section{Geographic implications of polarized tourism development}

Concentration is one of dominant characteristics of tourism development at the national level. The two Littoral regions have major significance for Croatian tourism while the continental regions play a marginal role.

One of the crucial questions of contemporary tourism development in Croatia is that of the expansion of tourism from the coastline inland. The fact is that differences between the littoral and continental regions are very pronounced. Because of this, the phrase tourism under-development is regularly mentioned when speaking about the continental regions, while the expression over-development is applied when dealing with the Littoral regions. Such a situation is the cause of various problems in the Littoral regions which are a result of excessive tourism concentration during the peak tourism season. This is the reason for the fact that, when discussing tourism development on the national level in the Croatian literature that deals with various tourism research projects (whether scientific or not, tourism expansion from the coast inland is regularly mentioned. The real problem is often overlooked and it arises from the dilemma on whether the continental regions should count on the expansion of tourism from the coast, or if they should rely primarily on independent self-generated tourism development. Current experiences show that tourists who spend their vacations at seaside destinations do not, in general, show an affinity towards taking excursions lasting more than one day. The benefit of one-day trips for a local municipality is very questionable and its effect cannot be compared with those of stationary tourism. Besides, tourists who stay at seaside destinations tend not to travel during the strong summer heat and, when they do, they travel short distances to visit the principal attractions (such as Plitvice Lakes National Park). An additional problem is the lack of adequate capacities in the continental parts of the country. Although the process of privatization has benefited private enterprises, the fragmentation of the tourism sector in Croatia has shown some negative effects. The crisis among big tourism enterprises (tour-operators), which could invest in tourism capacities in the continental hinterland, has had a negative impact on tourism. Small entrepreneurs are often reluctant to invest in tourism capacities because of the uncertainty which arises from the strong level of seasonality in the tourism sector (with peaks in July and August). Small travel agencies, together with local, mostly family-owned small hotels, regularly do not see the whole picture of tourism development at any level wider than the local. Turning towards the national tourists, especially to those from urban areas inside the continental regions, is a necessary strategy, although it is faced with different obstacles (one of them being the low mobility of the national population, currently re-enforced by the global financial crisis). From the geographic point of view, it can be said that, due to the polarized tourism development in Croatia, it is possible to distinguish the geographic core from the periphery. Although the very shape of the core can be described from the viewpoint of compactness and territorial discontinuity, it is obvious that it consists of the coastal area and the islands. The concept of peripherality 
and marginalization is well known in the scientific literature, including geographic literature. What the mechanisms of overcoming them are - if it is possible to overcome them at all - is a question that still stimulates discussion. The current concentration process in the case of Croatian tourism cannot be observed as something temporary or easily solved. The problems of such a development have become more visible in recent years in the form of road congestion, lack of parking spaces, traffic jams in the ferry ports and even water reductions at certain seaside and island destinations. Excessive orientation towards the tourism sector has formed a certain kind of dependency in the Littoral regions, while neglecting other activities such as industry or agriculture at the same time.

\section{Geographic aspect of tourism development inside the regions}

The results of the research show strong differences regarding tourism development inside each tourism region. Therefore, it can be stated that the process of polarized tourism development is evident not only at the national but also at the regional level. Since the principal destinations are situated on the narrow coastline zone, the aforementioned question of tourism expansion is relevant even in the Littoral regions. The concept of tourism expansion is more realistic in the case of each region than on the interregional level. Furthermore, because of the excessive tourism concentration along the coastline, it is a desirable development scheme, especially in coastal areas that are characterized by tourism saturation. For those parts of the Littoral regions, tourism expansion towards the hinterland is crucial and it serves as an additional attractive factor since it increases the existing tourism opportunities. The best example of such a development scheme is the peninsula of Istria in the region of the Northern Littoral. Although the inland destinations still do not register a tourism flow that is even close to that of the coastal destinations, their opening up of tourism is an encouraging sign with positive geographic effects, even though it is limited at present. It is not only the inland that benefits from such a process but also the coastline destinations, since it removes the pressure on tourism capacities, infrastructure and the construction land that they have at their disposal. The region of the Southern Littoral, on the other hand, still does not show similar development tendencies. The reason should not be sought in attractive factors, since the Southern Littoral's hinterland features a significant variety, but rather in the lack of local initiative connected with a shorter tourism tradition.

The situation in the continental regions is different to a certain extent since the question of tourism's role in the regions' economy is still not defined. Therefore, it is not clear if tourism should be a basis of regional development (and if so, in which areas) or whether it should be a subsidiary activity. In addition, the importance of tourism for the development of rural areas and smaller urban centres has not been extensively researched, the same as with the tendencies of its development in the near future. The significance of tourism as an additional source of income in circumstances of agricultural and industrial crises is an important question, which also needs to be answered from the scientific point of view. The traditional orientation of the Pannonian and Peripannonian Regions toward industry and agricultural production is the principal reason for the low level of its development, especially when comparing it with the two Littoral regions. Therefore, the current concentration of tourism in principal urban centres should be explained from the point of view of their 
roles as business and cultural centres. Such a situation puts them in a favourable position when compared with other parts of the three continental regions. Because of this, we can speak about the over-development of the focal tourism points, especially in the case of the national capital of Zagreb in the Peripannonian Region. In the Pannonian Region, the main destination is the city of Osijek, which features the best tourism capacities and therefore attracts the largest proportion of tourists. Even the tourists who visit the most important natural attraction of the region - such as the Kopački rit Nature Park, situated in the very vicinity of the city - tend to stay in the city instead of the other way around. The situation is different in the Mountainous Region, which does not have larger urban centres with a significant economic or cultural role. Its tourism primarily depends on abundant, still poorly exploited natural attractions, with the focal tourism point being the Plitvice Lakes National Park. The geographic situation of the Mountainous Region, in the very hinterland of the Littoral regions, offers significant possibilities for tourism development, which are as of yet insufficiently exploited. Since the problem of serious and constant population loss, along with the overall under-development that still burdens the region, it is a highly questionable if tourism can be raised to a higher level.

\section{From tourism concentration to where?}

All the presented information provides the relevant background for further analysis. The main issue may be formulated as the following question: is tourism dispersion a possible option in the near future, or should the current situation be accepted as what is realistic? Our research shows that the process of concentration is very much emphasized at the national and regional levels. It is a fact from which stems the dilemma of whether it is possible to divert or redirect tourism development, or should the present situation be the starting point for redefining and re-evaluating the current tourism policy. Observing from the present-day position, it would be more rational to control and direct the current tendencies rather than to try to reverse the present situation. Namely, how best to carry out the tourism expansion policy and what results it would show is very questionable. On the other hand, the focal tourism points, which have the role of concentration axes, cannot be restricted or limited in the present or future tourism development. Since beach tourism is the principal motive for the majority of national and international tourists, the coastal destinations will retain their dominant role within in the country. It is a generally accepted fact in Croatia that beach tourism will have such a position in the foreseeable future. We believe that the current situation of polarized tourism development should be accepted as the reality that is going to last for decades and that it will not be easily or significantly reversed. Instead of even trying to implement a short-term tourism policy, we propose the more demanding long-term pattern of tourism development that relies on three postulates.

The first postulate concerns building up the general quality of tourism opportunities and strengthening the promotion of various selective types of tourism. Such a development scheme is connected with a policy that would attract tourists and benefit the new destinations at the same time. The second postulate states that the new destinations should define their tourist attractions starting from the point of view of complementary tourism development. Such an approach could guarantee a stronger attraction base and the reliable position of the new destinations in the over-competitive tourism market in Croatia. And finally, the third 
assumption states that the destinations should interact more with each other in regard to tourism development, instead of just competing. Such an interaction should be arranged between the developed and the less developed ("new") destinations. This should be done primarily at the regional level because of the shorter distances involved.

In addition, it is possible to define propositions for making further policy decisions that would benefit even more the tourism development at the regional level. When dealing with the Littoral regions, our opinion is that the first step should lead toward the shaping of tourism policy, which would start from the present situation and progressively tend toward tourism expansion inside the regions. The Northern Littoral has already entered this stage and it can therefore work on the further growth of its destinations in the inland. On the other hand, the Southern Littoral still needs to take more decisive steps in that direction. At the same time, the shaping of tourism policy in the continental regions should rely on the recognition of principal attractions for both national and international tourists. A larger proportion of national tourists, primarily those from inside the respective regions, could be attracted through developing various selective types of tourism (such as agritourism, rural tourism, wellness, gastro-tourism, wine routes).

\section{CONCLUSION}

The geographically uneven development of tourism in Croatia has led to the formation of tourism centres that could be identified as the development poles. The process of concentration, which is evident at two levels - the national and regional - is one of the key geographic characteristics of Croatian tourism development. While the expansion of tourism from the (over)developed destinations on the coast toward the inland is generally mentioned as a solution to the current situation, the fact is that it is just one of the mechanisms that would lead towards tourism's more even diffusion. Simple mechanical expansion is possible and realistic in the case of the two Littoral regions, as experiences from the Northern Littoral show. On the other hand, the three continental regions should count on independent development, which cannot rely significantly on the Littoral regions. The continental regions are also more burdened with the problem of non-existent polycentric tourism development than the Littoral regions. It is unrealistic to expect that the continental regions should simply rely on the concept of the geographical expansion of tourism from the coastline toward the inland. The need for a more complex and thorough approach toward the tourism development of the continental regions, directed primarily toward national and regional markets, is the most realistic development scheme.

The results of tourism valorization for the year 2010 were published during the course of our research. As expected, no significant changes were observed in the two-year period. Therefore, the results of this research can be considered relevant. 


\section{REFERENCES}

Andrienko, G., Andrienko, N., Savinov, A., 2001: Choropleth maps: classification revisited, Proceedings of ICA 2001, Vol. 2, 1209-1219.

Batterson, M. J., Taylor, D. M., 2005: PGE results from selected samples along the southern shore of Conception Bay, Avalon peninsula (NTS map sheets 1N/6 and 1N/11), Geological Survey, Open File 1N/0757, Government of Newfoundland and Labrador, Department of Natural Resources, St. John's.

Blažević, I., 2009: Turistička geografija Hrvatske, Školska knjiga, Zagreb.

Blažević, I., Pepeonik, Z., 2002: Turistička geografija: svijet i Hrvatska, Školska knjiga, Zagreb.

Brenner, J., Jimenez, J. A., Sardá, R., 2006: Definition of Homogeneous Environmental Management Units for the Catalan Coast, Environmental Management 38, 993-1005.

Brewer, C. A., Pickle, L., 2002: Evaluation of methods for classifying epidemiological data on choropleth maps in series, Annals of the Association of American Geographers 94(2), 662-681.

Brunt, B. M., 1995: Regions and Western Europe, Journal of Geography 94(1), 306-316.

Claval, P., 1998: An introduction to regional geography, Blackwell Publishers, Oxford.

Chrest, D. P., Wheaton, W. D., 2009: Using Geographic Information Systems to Define and Map Commuting Patterns as Inputs to Agent-Based Models, RTI Press publication No. MR-0012-0906, TRI International Research Triangle Park.

Dieleman, F. M., Faludi, A., 1998: Randstad, Rhine-Ruhr and Flemish Diamond as one polynucleated macroregion?, Tijdschrift voor economische en sociale geografie, 89(3), 320-327.

Evans, I. S., 1977: The Selection of Class Intervals, Transactions of the Institute of British Geographers, New Series, Vol. 2(1), Contemporary Geography, 98-124.

Fürst-Bjeliš, B., 1996: Pristup definiciji prostornog pojma tradicionalne regije, u: I. hrvatski geografski kongres: geografija u funkciji razvoja Hrvatske: zbornik radova (ur. Pepeonik, Z.), Zagreb, 12. i 13. listopada 1995. Hrvatsko geografsko društvo, Zagreb, 326-330.

Graeff, C., Loui, M. C., 2008: Ethical implications of technical limitations in GIS, IEEE Technology and Society Magazine 27(4), 27-36.

Hall, O., Duit, A., Caballero, L. N. C., 2008: World Poverty, Environmental Vulnerability and Population at Risk for Natural Hazards, Journal of Maps, 151-160.

Holmén, H., 1995: What's new and what's regional in the "new regional geography"?,

Geografiska annaler, Series B, Human Geograhy 77 B (1), 47-63.

Holt, J. B., 2007: The Topography of Poverty in the United States: A Spatial Analysis Using County-Level Data From the Municipality Health Status Indicators Project, Preventing Chronic Disease 4(4), 1-9.

Jenks, G. F., Coulson, M. R., 1963: Class intervals for statistical maps, International

Yearbook of Cartography 3, 119-134.

Jenks, G. F., 1967: The Data Model Concept in Statistical Mapping, International Yearbook of Cartography 7, 186-190.

Jenks, G. F., 1977: Optimal Data Classification for Choropleth Maps, Occasional paper No. 2, Department of Geography, University of Kansas, Lawrence.

Jiang, B., Liu, X., 2011: Scaling of Geographic Space from the Perspective of City and Field Blocks and Using Volunteered Geographic Information, International Journal of Geographical Information Science iFirst, 1-15.

Mennis, J., Liu, J. W., 2005: Mining Association Rules in Spatio-Temporal Data: An Analysis of Urban Socioeconomic and Land Cover Change, Transactions in GIS 9(1), 5-17.

Murray, A. T., Shyy, T.-K., 2000: Integrating attribute and space characteristics in choropleth display and spatial data mining, International Journal of Geographical Information Science 14(7), 649-667. 
Nir, D., 1990: Region as a socio-environmental system - an introduction to a systemic regional geography, Kluwer Academic Publishers, Dordrecht.

Njegač, D., 2000: Regionalna struktura Hrvatske, u: II. hrvatski geografski kongres: zbornik radova (ur. Pejnović, D.), Lovran, 30. rujna - 3. listopada 1999., Hrvatsko geografsko društvo, Zagreb, 191-199.

Osaragi, T., 2002: Classification methods for spatial data representation, Centre for Advanced Spatial Analysis, University College London, Working paper series, Paper 40, London.

Papić, K., 1987: Koncepti regionalizacije, Dela 4, 80-89.

Paasi, A., 1986: The institutionalization of regions: a theoretical framework for understanding the emergence of regions and the constitution of regional identity, Fennia 164(1), 105-146.

Pászto, V., Tuček, P., Voženílek, V., 2009: On spatial entropy in geographical data, Sborník příspěvků 16. Konference GIS, 25.-28. siječnja 2009, Ostrava, 1-10.

Pater, B. D., 1989: A contextual approach to the concept of region in traditional regional

Geography, $u$ : Post-War Development of Regional Geography with special attention to the United Kingdom, Belgium and the Netherlands (ur. Paul, L. J.) Nederlandse Geografische Studies 86, Amsterdam-Utrecht.

Rana, S., Morley, J., 2002: Optimising visibility analyses using topographic features on the terrain. Centre for Advanced Spatial Analysis, University College London Working paper series, Paper 44, London.

Rogić, V., 1962: Fizionomska i funkcionalna regionalizacija Hrvatske, u: VI. kongres geografov FLRJ: zbornik radova, Ljubljana, 27. rujna - 5. listopada 1961., Savez geografskih društava FNRJ - Geografsko društvo Slovenije, Ljubljana, 279-290.

Rogić, V., 1963: Geografski koncept regije, Geografski glasnik 25(1), 113-122.

Rogić, V., 1983: Nacrt uvjetno homogene regionalizacije SR Hrvatske, Geografski glasnik 45(1), 75-89.

Rogić, V., 1984: Jednostavnost i fleksibilnost koncepta nodalno-funkcionalne diferencijacije SR Hrvatske, Geografski glasnik 46(1), 73-80.

Vresk, M., 1990: Grad u regionalnom i urbanom planiranju, Školska knjiga, Zagreb.

Vresk, M., 1995: Regionalna struktura Hrvatske - socioekonomske osnove strukturiranja, Geografski glasnik 57(1), 55-70.

Vresk, M., 1997: Uvod u geografiju-razvoj, struktura, metodologija, Školska knjiga, Zagreb.

Vresk, M., 1997a: Regionalna geografija danas, Acta Geographica Croatica 32, 69-82.

Weaver, C., 2006: Improvisational Geovisualization of the 2000 United States Census. AutoCarto 2006, 1-10.

\section{SOURCES}

Source: Tourism - Cumulative Data, 2009, Statistical Report 4.4.2, Croatian Bureau of Statistics, Zagreb, 2010. 


\title{
Suvremeni problemi regionalnog razvoja turizma u Hrvatskoj
}

\author{
Zoran Curić, Nikola Glamuzina, Vuk Tvrtko Opačić
}

U radu se analizira stupanj dosegnutoga turističkog razvoja najmanjih administrativnih jedinica u Hrvatskoj (gradova i općina) u pet turističkih regija: Sjevernom primorju, Južnom primorju, Gorskoj regiji, Peripanonskoj regiji i Panonskoj regiji. Metodološki pristup istraživanja temelji se na GIS analizi sedam relevantnih pokazatelja turističkog razvoja primjenom Jenksove metode prirodnih razreda: broja turističkih kreveta, turističkih dolazaka, međunarodnih turističkih dolazaka, turističkih noćenja, međunarodnih turističkih noćenja, turističkih dolazaka po površini i turističkih dolazaka po stanovniku. S obzirom na vrijednosti svakog od tih pokazatelja svaka je administrativna jedinica svrstana $u$ jedan od pet razreda koji opisuju dosegnuti stupanj turističkog razvoja: vrlo niski (1), niski (2), umjereni (3), visoki (4) i vrlo visoki (5). Na taj je način svakoj administrativnoj jedinici pridružena odgovarajuća oznaka stupnja turističkog razvoja na ljestvici od jedan do pet. Bitno je naglasiti kako su konačne ocjene usporedive samo na regionalnoj razini jer se granične vrijednosti za svaki od pet razreda razlikuju između regija, i to stoga što se regije znatno razlikuju u vrijednostima sedam navedenih pokazatelja.

Rezultati analize na nacionalnoj razini pokazuju dominaciju Sjevernog primorja kao turistički najrazvijenije regije, na koju je 2009. otpadalo više od polovine turističkog prometa i smještajnih kapaciteta. Na drugom je mjestu bilo Južno primorje s vrijednostima koje su se kretale od 39 do 44 posto, dok su tri kontinentalne regije zabilježile najniže vrijednosti. Također su uočljive razlike unutar svake turističke regije. U dvjema primorskim regijama geografske razlike primjetne su između obale, koja prednjači u turističkom razvoju, te otoka, koji još uvijek zaostaju u turističkom prometu. Najniži stupanj turističkog razvoja bilježe administrativne jedinice u zaleđu. U Peripanonskoj i Panonskoj regiji razlike su naglašene između područja velikih gradova, koji se ističu turističkom razvijenošću, te ostalih administrativnih jedinica. Izuzetak je Gorska regija, u kojoj jedino Nacionalni park „Plitvička jezera” prednjači po stupnju turističke valorizacije.

Geografske su posljedice neujednačenoga turističkog razvoja izražene ponajprije kroz koncentraciju turizma u dvjema primorskim regijama uz istodobnu marginalizaciju triju kontinentalnih regija. Pitanje širenja turizma iz primorskih prema kontinentalnim regijama vrlo je upitno zbog sezonalnosti turizma, nedostatka smještajnih kapaciteta, fragmentiranosti turističkog sektora i slabe pokretljivosti domaćeg stanovništva. Ipak, za kontinentalne je regije znatno realnija opcija okretanja prema većim gradovima unutar njih, kao glavnim emitivnim područjima, umjesto oslanjanja na dolazak međunarodnih turista koji borave u primorskim regijama. Polarizacija u turističkom razvoju vidljiva je i na regionalnoj razini. Do sada su jedino na području Istre napravljeni pomaci prema rasterećivanju obalnih turističkih destinacija, i to zahvaljujući turističkom razvoju zaleđa te povezivanju obalnih odredišta s onima u zaleđu. S druge strane, u kontinentalnim je regijama primjetan proces izrazite koncentracije i centralizacije turizma unutar pojedinih točaka, kao što su Zagreb (u Peripanonskoj regiji), Osijek (u Panonskoj regiji) ili Plitvice (u Gorskoj regiji). Činjenica je da je koncentracija turizma na nacionalnoj razini previše odmakla da bi probleme koje generira taj proces bilo moguće riješiti jednostavnim preusmjerivanjem turista 
prema kontinentalnim regijama. Stoga bi bilo racionalnije prihvatiti sadašnju situaciju kao realnost te pokušavati usmjerivati daljnji turistički razvoj, a ne nastojati preokrenuti njegove razvojne trendove, i to povećavanjem kvalitete turističkih usluga, razvojem raznih selektivnih oblika turizma te suradnjom razvijenih i novih turističkih turističkih odredišta, ponajprije na regionalnoj razini.

Received (Primljeno): 2012 - 03 - 28

Accepted (Prihvaćeno): 2012 - $05-25$

Zoran Curić, PhD, Full Professor

University of Zagreb

Faculty of Science

Department of Geography

Marulićev trg 19/II, 10000 Zagreb, Croatia

zcuric@geog.pmf.hr

Nikola Glamuzina, $\mathrm{PhD}$, Associate Professor

University of Split

Faculty of Philosophy

Sinjska 2, 21000 Split, Croatia

Nikola.Glamuzina@ffst.hr

Vuk Tvrtko Opačić, PhD, Assistant Professor University of Zagreb

Faculty of Science

Department of Geography

Marulićev trg 19/II, 10000 Zagreb, Croatia

vtopacic@yahoo.com 